\title{
Diglosia antara bahasa Jawa dan Sunda (study kasus masyarakat bahasa kecamatan Lemah Abang Kabupaten Cirebon)
}

\author{
Endang Iryani, \\ (Program studi Bahasa Inggris, Fakultas Keguruan dan Ilmu Pendidikan Universitas MH. Thamrin)
}

\begin{abstract}
ABSTRAK
Diglosia merupakan fenomena masyarakat yang menggunakan dua bahasa dalam kehidupan seharihari. Diglosia hampir mirip dengan bilingual akan tetapi diglosia berdasarkan teori Fishman memiliki tarap bahasa tinggi dan bahasa rendah. Penelitian yang dilakukan di kecamatan Lemah Abang Kabupaten Cirebon Jawa Barat merupakan penelitian deskriptif terhadap diglosia bahasa Jawa dan Sunda di masyarakat pengguna bahasa Lemah Abang.

Penelitian ini menggunakan metode Kualitatif dengan pendekatan Fenomologi. Penelitian ini menjabarkan keadaan bahasa Jawa dan Sunda yang terdapat pada masyarakat kecamatan Lemah Abang dalam kehidupan sehari-hari. Analisa diglosia yang digunakan oleh penulis menggunakan teori Ferguson, yakni Fungsi, Prestise, Pemerolehan, Standardisasi, Stabilitas, Gramatika, Leksikon, dan Fonologi.

Hasil penelitian ini menunjukan bahwa pertama bahasa jawa digunakan oleh masyarakat kecamatan Lembah Aban lebih banyak digunakan pada saat transaksi perdagangan dan bisnis lainya. Kedua, ada garis teritorial bahasa pada kecamatan Lembah Abang, desa lemah abang mayoritas bahasa yang digunakan adalah jawa sedangkan desa Sindang Laut dan Asem adalah bahasa Sunda. Ketiga, masyarkat yang bahasa ibunya dalah bahasa sunda hampir masyarakatnya mampu menggunakan bahasa jawa dengan aksen dan itonasi mirip dengan pengguna bahasa jawa sebagai bahasa ibu. Sedangkan masyarakat bahasa jawa ketika menggunakan bahasa sunda terkendala dengan aksen dan intonasinya.
\end{abstract}

\section{Latar belakang}

Bahasa merupakan alat komunikasi manusia dalam menyampaikan pesan antar sesama. Dalam fungsinya, bahasa mampu merubah keadaan seseorang tanpa disadari dan disadari, seperti marah, bahagia dan sedih. Orang akan marah ketika dia mendapatkan pesan yang menyinggung perasaan dirinya. Dan orang akan bahagia ketika dia mendapatkan kata-kata yang mampu membangkitkan rasa ketengan dan rangsangan semangat hidup melalui otak kanannya.

Dalam fungsi keseharian, bahasa berguna juga sebagai alat komunikasi pengantar hubungan ekonomi atau bisnis. Bisnis akan berjalan dengan lancar ketika kedua orang tersebut mampu berkomunikasi dengan baik dan berakhir saling menguntungkan. Sehingga dapat disimpulkan bahwa bahasa merupakan alat dan sistem bagi manusia, seperti yang dikatakan oleh Sibarani (2004:37) Bahasa adalah bahasa sebagai sistem tanda atau sistem lambang, sebagai alat komunikasi, dan digunakan oleh kelompok manusia atau masyarakat.

Kaitan bahasa dengan pengguna bahasa (masyarakat) dalam kajian ilmu bahasa masuk dalam ranah keilmuan sosilinguistik. Fishman (1972) dalam Chaer dan Agustina (2004:3) mengemukakan bahwa sosiolinguistik adalah kajian tentang ciri khas variasi bahasa, fungsi variasi bahasa, dan pengunaan bahasa karena ketiga unsur ini berinteraksi dalam dan saling mengubah satu sama lain dalam satu masyarakat tutur, identitas sosial dari penutur, lingkungan sosial tempat peristiwa tutur terjadi serta tingkatan variasi dan ragam linguistik. Jadi masyarakat adalah penentu dari munculnya keanekaragaman bahasa. 
Negara Indonesia merupakan Negara yang memiliki kekayaan bahasa. Lebih dari 100 bahasa daerah terdapat di negara ini. Dua dari bahasa daerah yang berada di negara indonesia adalah bahasa Jawa dan Sunda. Dua bahasa ini terdapat dipulau Jawa dan memiliki pengguna yang banyak dibandingkan bahasa daerah lainnya. Dua bahasa tersebut juga memiliki keanekaragamaan tersendiri berdasarkan garis linguistik. Bahasa Sunda yang berada di Jawabarat memiliki perbedaan aksen, kosakata dan pengucapan dengan bahasa sunda Banten. Begitu juga bahasa Jawa. Bahasa jawa yang berada di Banten dan Jawa Barat berbeda dengan bahasa Jawa yang berada di Jawa Timur dan Jawa Tengah.

Begitu luas dan beragamnya bahasa Jawa dan Sunda, pada konteks ini, peneliti akan memberikan batas analisa bahasa yang diteliti pada bahasa Jawa dan Sunda yang berada di Cirebon Jawa Barat. Peneliti tertarik dengan penggunaan bahasa Jawa dan Sunda yang terjadi di Desa Lemah Abang Cirebon. Masyarakat ini memiliki dua bahasa yang digunakan dalam kehidupannya, yakni bahasa Jawa khas Jawa Barat dan Bahasa Sunda. Maksud dari khas ini, bahasa Jawa yang digunakan oleh masyarakat Jawa Barat memiliki aksen berbeda dengan bahasa Jawa yang berada di Jawa Tengah dan Timur. Dalam pandangan orang Jawa (penggunan Bahasa Jawa), bahasa Jawa yang digunakan merupakan bahasa "kasar" yang ada pada wilayah Cirebon.

Keunikan masyarakat Lemah Abang adalah penggunaan dua bahasa (Sunda dan Jawa) dalam kehidupan sehari-harinya, dan hampir semua orang lembah abang menguasai dua bahasa tersebut. Padahal bahasa ibu mereka adalah bahasa sunda (berdasarkan garis teritorial bahasa) sebab mereka lebih dekat ke Kuningan (wilayah Jawa Barat berbahasa Sunda) dari pada kota Cirebon. Hal ini menjadi perhatian peneliti untuk melihat dari sudut pandang Sociolinguistik; Diglosia.

Kata diglosia berasal dari bahasa Prancis diglossie. Dalam pandangan Ferguson menggunakan istilah diglosia untuk menyatakan keadaan suatu masyarakat di mana terdapat dua variasi dari satu bahasa yang hidup berdampingan dan masing-masing mempunyai peranana tertentu.

\section{Lingkup penelitian}

Penelitian ini akan fokus pada fenomena Diglosia; penggunaan bahasa Jawa dan Sunda di Lemah Abang Cirebon. Peneliti akan melakukan analisa terhadap penggunaan dua bahasa tersebut didalam kehidupan sehari-hari masyarakat Lemah Abang cirebon.

\section{Permasalahan Penelitian}

Kecamatan Lemah Abang merupakan salah satu kecamatan yang berada di Kabupaten Cirebon. Kecamatan ini adalah wilayah yang berbatasan langsung dengan kabupaten Kuningan, dimana dua kabupaten ini memiliki bahasa dan budaya yang berbeda. Cirebon dominan masyarakatnya menggunakan bahasa jawa sedangkan kuninga bahasa Sunda. Masyarakat lemah abang mengunakan kedua bahasa tersebut (Sunda dan Jawa). hal ini yang membuat peneliti tertarik akan fenomena masyarakat bahasa pada kecamatan Lemah Abang. Sehingga penelitian ini akan menjelaskan bagaimana fenomena diglosia bahasa Jawa dan Sunda di kecamatan Lemah Abang?

\section{Metode Penelitian}

Penelitian ini menggunakan metode penelitian Kualitatif dengan pendekatan Fenomenologi. Dimana penelitia melakukan oservasi langsung kelapangan dengan melihat keadaan masyarakat dalam menggunakan bahasa Jawa dan Sunda tersebut. Untuk memperkuat data, peneliti melakukan wawancara dengan beberapa warga yang dilakukan secara random berdasarkan rumusan sampling. Data yang terkumpul akan dilakukan tabulasi dan dijabarkan secara naratif.

\section{Kajian Teoritis}

Sosiolinguistik merupakan disiplin ilmu yang mempelajari dua hal; sosial (masyarakat) dan bahasa. Kajian ilmu ini adalah menganalisa pola atau tingkah masyarakat yang dinalisa melalui penggunaan 
bahasa pada masyarakat tersebut. Salah satu toeri dari ilmu sosiolinguistik adalah diglosia. Diglosia adalah suatu situasi bahasa di mana terdapat pembagian fungsional atas variasi-variasi bahasa atau bahasa-bahasa yang ada di masyarakat.

Kata diglosia berasal dari bahasa prancis diglossie, yang pernah digunakan oleh Marcais, seorang lingu Prancis: tetapi istilah itu menjadi terkenal dalam studi sosiolingustik setelah digunakan oleh seorang swarjana dari Stanford University, yaitu C.A. Ferguson tahun 1958 dalam suatu symposium tentang "Urbanisasi dan bahasa-bahasa standar" yang diselenggarakan oleh American Anthropological Association di Washinton DC. Kemudian Ferguson menjadikan lebih terkenal lagi istilah tersebut dengan sebuah artikelnya yang berjudul "diglosia".

Ferguson membuat sembilan poin dalam menganalisa fenomena diglosia di masyarakat. Poin-poin ini yang mampu membedah keberadaan diglosia di masyarakat, dalam penelitian ini juga penulis menggunakan pendekatan sembilan poin diglosia dari Ferguson untuk menganalisa diglosia bahasa Jawa dan Sunda. Adapun sembilan poin tersebut adalah sebagai berikut:

a. Fungsi

Merupakan kriteria diglosia yang sangat pentin. Menurut ferguson dalam masyarakat diglosis terdapat dua variasi dari satu bahasa. Variasi pertama disebut dialek tinggi (disingkat dialek T atau ragam $\mathrm{T}$ ), dan yang kedua disebut dialek rendah (disingkat dialek $\mathrm{R}$ atau ragam $\mathrm{R}$ ).

b. Prestise

Dalam masyarakat diglosis para penutur biasanya menggunakan dialek $\mathrm{T}$ lebih bergengsi, lebih superior, lebih terpandang, dan merupakan bahasa yang logis. Sedangkan dialek R dianggap inferior, malahan ada yang menolak keberadaannya.

c. Warisan Kesusastraan

Pada tiga dari empat bahasa yang digunakan Ferguson sebagai contoh terdapat kesusastraan di mana ragam $\mathrm{T}$ yang digunakan dan dihormati oleh masyarakat bahasa tersebut. Kalau ada juga karya sastra kontemporer dengan menggunakan ragam $\mathrm{T}$, maka dirasakan sebagai kelanjutan dari tradisi itu, yakni bahwa karya sastra harus dalam ragam $T$. tradisi kesusastraan yang selalu dalam ragam $\mathrm{T}$ ini (setidaknya dalam empat contoh di atas) menyebabkan kesusastraan itu tetap berakar, baik di Negara-negara berbahasa arab, bahasa yunani, bahasa prancis, dan bahasa jerman.

d. Pemerolehan

Ragam $\mathrm{T}$ diperoleh dengan mempelajarinya dalam pendidikan formal, sedangkan ragam $\mathrm{R}$ diperoleh dari pergaulan dengan keluarga dan teman-teman sepergaulan.

e. Standardisasi

Ragam $\mathrm{T}$ dipandang sebagai ragam yang bergengsi, maka tidak mengherankan kalau standarisasi dilakukan terhadap ragam $\mathrm{T}$ tersebut melalui kodifikasi formal.

f. Stabilitas

Kesetabilan dalam masyarakat diglosia biasanya telah berlangsung lama, dimana ada sebuah variasi bahasa yang dipertahankan eksistensinya dalam masyarakat itu.

g. Gramatika

Dalam ragam $\mathrm{T}$ adanya kalimat-kalimat kompleks dengan sejumlah konstruksi subordinasi adalah hal yang biasa, tetapi dalam ragam $\mathrm{R}$ diangap artificial.

h. Leksikon

Sebagian besar kosakata pada ragam $\mathrm{T}$ dan ragam $\mathrm{R}$ adalah sama. Namun, ada kosakata pada ragam $T$ yang tidak ada pasangannya pada ragam $R$, atau sebaliknya.

i. Fonologi

Dalam bidang fonologi ada perbedaan structural antara ragam $\mathrm{T}$ dan ragam R. Perbedaan tersebut bisa dekat bisa juga jauh.

Fasold (1984) seorang ahli bidang sosiologi, menjabarkan diglosia dengan luas. Dalam pandangan dia bahwa dilogisa itu tidak hanya dua bahasa akan tetapi lebih dari dua ragam bahasa atau dialek yang 
ada dilingkungan masyarakat. Dalam pandangannya ini, Fasold mengembangkan konsep diglosia ini menjadi apa yang disebutkan broad diglosia (diglosia luas). Fasold juga membuat istilah double overlapping diglosia, dobule nested diglosia dan linear polyglosia. Istilah-istilah ini untuk membedakan tingkat keadaan masyarakat pada tingkatan fungsi kebahasaan.

Expert sosilogi lain yang mengembangkan teori diglosia adalah Fishman (1972: 92). Menurut dia diglosia adalah " ... diglossia exits not only in multilingual societies which offocially recognize several "language", and not only in societies which employ separate dialects, registers, or funcitonally differentiated language varieties of whatever kind" (... diglosia tidak hanya terdapat di dalam masyakat aneka bahasa yang secara resmi mengakui beberapa bahasa", dan tidak hanya terdapat terdapat di dalam masyarakat yang menggunakan ragam sehari-hari dan klasik, tetapi terdapat juga di dalam masyaakat bahasa yang memakai logat-logat, laras-laras, atau ragam-ragam jenis apapun yang berbeda secara fungsional.

Dalam pandangan Fishman bahwa diglosia tidak hanya dikenakan pada ragam tingi dan rendah dari bahasa yang sama akan tetapi juga dikenakan pada bahasa yang sama sekali tidak serumpun. Yang menjadi tekanannya adalah perbedaan fungsi kedua bahasa atau ragam bahasa yang bersangkutan.Selain itu, Fishman juga berpandangan bahwa diglosia bisa terjadi pada masyarakat yang mengenal lebih dari dua bahasa, tidak hanya pada pada masyarakat yang mengenal satu bahasa dengan dua ragam saja tetapi juga pada masyarakat yang mengenal lebih dari dua bahasa.Ragamragam bahasa itu mengisi alokasi fungsi masing-masing dan bahwa ragam $\mathrm{T}$ hanya dipakai di dalam situasi resmi dan ragam $\mathrm{R}$ di dalam situasi yang tidak atau kurang resmi. Sehingga Fishman membagi beberapa diglosia berdasarkan masyarakatnya, yaitu:

1. Masyarakat bahasa yang bilingual sekaligus diglosik,

2. Masyarakat bahasa yang bilingual tetapi tidak diglosik,

3. Masyarakat yang tidak bilingual dan sekaligus tidak diglosik,

\section{Hasil Penelitian dan Pembahasan}

Desa Lemah Abang Kecamatan Lemah Abang Kabupaten Cirebon memiliki dua bahasa yang digunakan dalam kehidupan sehari-hari, yakni bahasa Sunda dan Jawa. bahasa Sunda yang digunakan lebih pada style gaya bahasa sunda Majalengka dengan ciri khas penggunaan kata "palay" yang memiliki arti " ingin". Pada tatanan bahasa sunda Jawa Barat kata "palay" hanya digunakan pada wilayah Majalengka dan Sindang laut Lemah Abang Cirebon, tidak digunakan pada semua wilayah Pasundan di Jawa Barat. Kebanyakan orang Pasundan menggunakan kata "Hoyong" untuk mengungkapkan kata "ingin".

Bahasa Jawa yang digunakan oleh masyarakat Lemah Abang adalah bahasa Jawa yang cenderung mirip dengan bahasa Jawa yang digunakan di Indramayu dan wilayah Serang Provinsi Banten. Masyarakat Lemah Abang mengatakan bahwa bahasa Jawa yang digunakan oleh mereka adalah Bahasa Jawa "kasar". Perbedaan bahasa Jawa Jawa Barat ini memang beda dengan bahasa Jawa yang digunakan di wilayah Jawa Tengah, dan Timur. Perbedaan yang sangat mencolok pada stye dan intonasi dari bahasa Jawa tersebut, misalnya pada kata "mere dikit kang" yang artinya " silahkan kesini kang".

Masyarakat Lemah Abang lebih dominan menggunakan bahasa Jawa ketika mereka transaksi Bisnis, seperti perdagangan. Para pedagang yang dipasar cenderung menggunakan bahasa Jawa, hal ini dipengaruhi dua faktor; pertama, pasar Lembah Abang merupakan salah satu pasar besar yang ada di kecamatan Lemah Abang sehingga banyak pembeli yang datang dari berbagai pelosok Kecamatan Lembah Abang. Kedua, hampir marketing atau pensuplai barang dagangan yang datang kepasar adalah orang-orang cirebon yang berasal dari Tegal Gubug, dimana mereka menggunakan bahasa Jawa sebagai bahasa komunikasi, sehingga pedagang pasar Lemah Abang harus menguasai bahasa 
jawa sebagai komunikasi dengan para marketing tersebut. Hal ini bertujuan agar harga yang ditawarkan tidak terlalu tinggi dan mereka dapat ke ringan tagihan dari marketing.

Jika melihat dominasi bahasa dalam masyarakat, bahasa sunda merupakan bahasa dominan yang ada pada wilayah Lemah Abang, sebab teritorial wilayah ini bersebelah langsung dengan Kuningan, yang mana Kuningan adalah bahasa Sunda sebagai bahasa pengantarnya. Hampir 70\% desa diwilayah dari Lemah Abang yang menggunakan bahasa sunda dalam kehidupannya, seperti Desa Asem, Desa Susukan, Desa Susukan Kaler, dan lainya. Pada wilayah-wilayah ini mereka menggunakan bahasa sunda dalam komunikasi keluarga.

Akan tetapi warga yang bahasa ibunya adalah bahasa sunda, mereka mampu berkomunikasi dengan bahasa jawa. lagi-lagi mereka gunakan bahasa jawa ketika mereka bertransaksi di pasar disaat mereka melakukan jual beli dan si penjual adalah orang Cirebon yang menggunakan bahasa Jawa, maka warga sunda ini pun menggunakan bahasa jawanya ketika bertransaksi.

Jika menggunakan pendekatan Furgosen dengan bahasa Jawa adalah T dan bahasa Sunda adalah $\mathrm{R}$ maka bisa dianalisa dalam beberapa poin diglosia, yakni:

a. Fungsi

Bahwa bahasa Jawa berfungsi sebagai komunikasi transaksi bisnis dikala mereka bertemu dengan pelaku bisnis yang berbahasa Jawa salah satunya warga Astanajapura, desa Lemah Abang yang menggunakan bahasa Jawa sebagai bahasa sehari-hari. Sedangkan bahasa Sunda di gunakan sebagai komunikasi sehari-hari dikehidupan keluarga bagi sebagaian besar warga kecamatan Lemah Abang.

b. Prestise

Tidak ada ragam yang tinggi (T) atau rendah (R) pada diglosia Jawa dan Sunda di kecamatan Lemah Abang. Posisi kedua bahasa tersebut sama dan tidak ada "derajat" bahasa.

c. Pemerolehan

Ragam $\mathrm{T}$ diperoleh dari pergaulan bagi komunitas masyarakat yang menggunakan ragam $\mathrm{R}$, sedangkan komunitas ragam $\mathrm{T}$ memperoleh bahasanya dari bahasa ibu sendiri.

d. Standardisasi

Seperti yang telah di jelaskan pada poin $b$ bahwa tidak ada "derajat" diantara ragam $\mathrm{T}$ dan R.

Standarisasi pada ragam $\mathrm{T}$ dipandang sebagai ragam alat komunikasi dalam berdagang atau bisnis sehingga penggunaan ragam $\mathrm{T}$ dominasinya terjadi pada ruang lingkup jual beli di pasar Lemah Abang sendiri.

e. Stabilitas

Diglosia yang terjadi pada kecamatan Lemah Abang sudah berlangsung lama, data dan analisa penulis hal ini disebabkan garis teritorial bahasa. Kecamaan Lemah Abang bersebelahan dengan kecamatan Astajanapura, dimana masyarakatnya menggunakan bahasa Jawa dalam komunikasi sehari-hari, dinamika kehidupan yang terjadi menjadikan adanya perubahan masyarakat dalam hal ini komposisi kependudukan bahasa. Tidak sedikit warga Astanajapura yang kemudian tinggal di kecamatan Lemah Abang, dengan alasan pernikahan, dan ekonomi. Sehingga hal itu menyebabkan adanya penambahan masyarakat bahasa pada wilayah kecamatan Lemah Abang.

Sedangkan Sindang Laut yang merupakan wilayah dari Kecamatan Lemah Abang merupakan penggunan bahasa Sunda dalam kehidupan sehari-hari. Masyarakat ini memiliki ragam bahasa sunda sebagai bahasa ibu, juga wilayah ini berdekatan dengan perbatasan wilayah kabupaten Kuningan yang notabennya pengguna bahasa sunda. Sehingga hal ini berdampak atau memberikan pengaruh yang signifikan terhadap keberadaan bahasa sunda pada kecamatan Lemah Abang. 
f. Gramatika

Melihat dari komposisi masyarakat diglosia kecamatan Lemah Abang, penulis bisa menjabarkan bahwa penggunaan ragam $\mathrm{T}$ jarang menggunakan ragam $\mathrm{R}$ untuk berkomunikasi dengan masyarakat penggunaan ragam $\mathrm{R}$. Walaupun sering ada penggunaan ragam $\mathrm{R}$ oleh masyarakat ragam $\mathrm{T}$ tetapi tidak selaras dengan intonasi kalimat ragam $\mathrm{R}$. Hasilnya akan terdengar asing atau terlalu dipaksa. Sedangkan pada masyarakat ragam $\mathrm{R}$ ketika menggunakan ragam $\mathrm{T}$ akan terdengar seperti masyarakat ragam $\mathrm{T}$ dalam struktur kalimat dan intonasinya.

g. Leksikon

Hanya sebagian kecil kosakata yang memiliki makna sama antara ragam R dan T. Penulis melihat salah satu kosakata ini sering digunakan oleh kedua ragam tersebut dalam fungsi dan makna yang sama, yakni menyetujui. Kosakata tersebut adalah "enggih" yang artinya "iya". Secara keseluruhan kosakata dan gramatikal bahasa kedua ragam tersebut memiliki perbedaan yang kuat. Seperti kata "arep ndi mas?" dengan "bade kamana?" kedua kosa kata ini memiliki makna sama yaitu mempertanyakan orang lain "mau pergi kemana?".

h. Fonologi

Dalam bidang fonologi ada perbedaan structural antara ragam $\mathrm{T}$ dan ragam R. Perbedaan tersebut bisa dekat bisa juga jauh.

\section{Referensi}

Abdul Chaer \& Leonie Agustina, Sosiolinguistik Suatu Pengantar, Jakarta, Rineka Cipta, cet-1,1995

Nababan, PWJ., Sosiolinguistik Suatu Pengantar, Jakarta: Gramedia Pustaka Utama, cet-4, 1993

Alwasilah, A. Chaedar. 1990. Sosiologi Bahasa. Bandung: Angkasa

Aslinda dan Leni Syafyahya. 2007. Kedwibahasaan, Dwibahasawan, dan Diglosia. Bandung: Refika Aditama.

Chaer, Abdul dan Leonie Agustina. 2004. Sosiolinguistik. Jakarta: Rineka Cipta

Sumarsono. 2007. Sosiolinguistik. Yogyakarta: Sabda

Badudu,J.S.1989. Inilah Bahasa Indonesia Yang Benar. Jakarta: PT. Gramedia

Pateda, Mansyur.1987. Sosiolinguistik. Bandung:Angkasa 